\title{
Cold Trauma in the Structure of External Causes of Mortality and Disability in the Republic of Sakha (Yakutia)
}

\author{
Alexander F. Potapov, $\mathrm{PhD}, \mathrm{ScD}^{1}$; Albina A. Ivanova, $\mathrm{PhD}, \mathrm{ScD}^{1}$; \\ Revo Z. Alekseev, PhD, ScD ${ }^{1}$; Svetlana V. Semenova ${ }^{2}$ \\ ${ }^{1}$ M. K. Ammosov North-Eastern Federal University ${ }^{2}$ Center for Emergency Medical Care of Yakutsk \\ Yakutsk, the Republic of Sakha (Yakutia), Russia
}

\begin{abstract}
The purpose of this study was to analyze the data of official medical statistics on mortality and disability in the Republic of Sakha (Yakutia) (RS(Y)) as a result of exposure to excessively low natural temperatures. For the retrospective epidemiological analysis, we used the data of the official statistics of RS(Y) for 2011-2015, data on the disability of the Federal State Institution "Main Bureau of Medical and Social Expertise of RS(Y)" for 2014-2016, and data of the burn department of the Center for Emergency Medical Care of Yakutsk for 2014-2016. In Yakutia, during 2011-2015, 662 people died in road accidents, and 812 died as a result of exposure to excessive natural cold; the mortality rates were 13.8 and 17.0 per 100,000 population, respectively. In the structure of external causes of mortality, the share of cold trauma in 2015 was 10.4\% (15.1 per 100,000 population), which put cold trauma in the third rank after suicide and murders, having displaced road accidents in fourth place $(5.6 \%, 7.8$ per 100,000 population). The disability rate due to frostbites was 1.19 per 100,000 population in 2014 and 1.73 per 100,000 population in 2015 and 2016. (International Journal of Biomedicine. 2018;8(3):228-231.)
\end{abstract}

Key Words: excessive natural cold $\bullet$ hypothermia $\bullet$ frostbites $\bullet$ disability rate mortality rate

\section{Introduction}

The threat to public health (disability, premature mortality) posed by exposure to low natural temperatures is one of the poorly understood health problems. The data in scientific publications testify to the relevance of this issue on a global scale. Thus, in the USA for the period between 2003 and 2013, 13,419 deaths from hypothermia were recorded $-0.3-0.5$ deaths per 100,000 population. The share of males was $67 \%$; there is also an age-specific feature: for persons over 65 years this coefficient was 1.8-1.1 deaths per 100,000 population. (1) In Sweden, mortality as a result of hypothermia, frostbite and hypothermia in cold water is $3.4,1.5$ and 0.8 cases per 100,000 population, respectively. The mortality rate for severe hypothermia varies from $12 \%$ to $80 \%$, according to foreign literature, and depends on the age, predisposing factors, and the causes and timing of the initiation of treatment. ${ }^{(2)}$ This problem is especially acute in Russia, whose vast territories

*Corresponding author: Prof. Albina A. Ivanova, PhD, ScD. M.K. Ammosov North-Eastern Federal University, Yakutsk, the Republic of Sakha (Yakutia),Russia.E-mail: iaa_60@mail.ru are located in the northern latitudes. In the Amur Region, in a specialized department for treatment of victims with thermal lesions, patients with cold trauma (CT) account for $12 \%-19 \%$ (60-90 people per year). The marginal rate of hospitalization of patients with $\mathrm{CT}$ in the Chita region is 1.9 cases per 10,000 population per year. ${ }^{(3)}$

The Republic of Sakha (Yakutia) (RS(Y)) is the largest subject of Russia, occupying about 3.1 million square kilometers, and more than $40 \%$ of its territory lies above the Arctic Circle. On 01/01/16, the population of $\mathrm{Rs}(\mathrm{Y})$ numbered 959,600 people, with a population density of 0.3 inhabitants per $1 \mathrm{~km}^{2}$. In $\mathrm{RS}(\mathrm{Y})$, the cold season lasts 7 months a year with an average winter temperature of -35 to $-40^{\circ} \mathrm{C}$. In such conditions, CT occupies a special place in the structure of causes of mortality from external causes, being an acute medical and social problem.

It should be noted that the medical and demographic situation in $\mathrm{RS}(\mathrm{Y})$ is characterized by a high level of premature mortality from preventable causes, especially accidents, injuries and poisonings. During the period between 1990 and 2014 , in the structure of the causes of mortality, external causes consistently occupied the second ranked place after diseases of 
the circulatory system. Between 2010 and 2015, the mortality rate from external causes decreased by $30.3 \%$ (from 195.3 to 136.2 per 100,000 population); but different dynamics were noted in the types of external causes. For example, along with a significant reduction in the level of violent deaths (murders, suicides), there has been an increase in the death rate from accidental alcohol poisoning. ${ }^{(4)}$

Official statistics attribute the causes of mortality from external causes mainly to road accidents, violence, accidental alcohol poisoning, accidental drowning, accidental falls, and so on. CT is taken into account among the "other" reasons, and therefore the true picture of the scale of the disaster, at least for $\mathrm{RS}(\mathrm{Y})$, remained hidden.

The purpose of this study was to analyze the data of official medical statistics on mortality and disability in RS(Y) as a result of exposure to excessively low natural temperatures from 2011 to 2015.

\section{Materials and Methods}

For the retrospective epidemiological analysis, we used the data of the official statistics of RS(Y) for 2011-2015, data on the disability of the Federal State Institution "Main Bureau of Medical and Social Expertise of RS(Y)" for 2014-2016, and data of the burn department of the Republican Hospital \#2 - the Center for Emergency Medical Care of Yakutsk - for 2014-2016. For the study of mortality, Diagnosis Code X31 of ICD-10 (Exposure to excessive natural cold [EENC]) was selected; for the study of disability - Codes T33.2 (Superficial frostbite of thorax), T34 (Frostbite with tissue necrosis), T35 (Frostbite involving multiple body regions and unspecified frostbite), and T69.8 (Other specified effects of reduced temperature).

\section{Results}

Analysis of statistical data revealed that more people die from cold trauma every year in RS(Y) than in road accidents. In Yakutia, during 2011-2015, 662 people died in road accidents, and 812 died as a result of EENC; the mortality rates were 13.8 and 17.0 per 100,000 population, respectively (Table 1 ).

The largest share of deaths $(80.3 \%)$ was made up by people of working age, including $78 \%$ by men aged between 16 and 59 and $22 \%$ by women aged between 16 and 54 .
In general, the dynamics of the mortality rate from EENC has a positive tendency - a decrease by $35.1 \%$ during 2011 2015 from 20.4 to 15.1 per 100,000 population. However, in the structure of external causes of mortality, the share of CT in 2015 was $10.4 \%$ (15.1 per 100,000 population), which put CT in the third rank after suicide and murders, having displaced road accidents in fourth place $(5.6 \% ; 7.8$ per 100,000 population).

According to data of the Center for Emergency Medical Care of Yakutsk, a specialized department for patients with thermal trauma receives about 200 EENC victims each year, and a combination of frostbite of limbs of different degrees with general cooling is about 10\%. In 2014-2016, 513 patients (17.9 per 100,000 population) received specialized treatment for frostbite and general hypothermia, including 33 children $(6.4 \%)$. Severe frostbites with tissue necrosis occurred in $35.0 \%$ $(\mathrm{n}=179)$ of all cases, including 5 children $(1.0 \%)$. Due to the severity of the injury, 7 patients died; hospital mortality was $1.4 \%$ (Table 2); and 251(49\%) patients suffered various surgical interventions for frostbite, including 187(36.5\%) patients who underwent amputation of the extremities (Table 3).

Undoubtedly, the amputation of extremities is a serious bodily injury, resulting in a restriction of physical possibilities and a deterioration in the quality of life. At the same time, there was a discrepancy between the number of persons who underwent amputation of limbs and the number of persons recognized as disabled for this reason. For example, in 2014-2016, 40 people underwent amputation of the lower extremities at the level of the shins and feet and 9 people amputation of the hand at the level of the forearm and hand (not counting the cases of finger amputation), but of these only 14 were recognized as disabled.

The disability rate due to frostbites was 1.19 per 100,000 population in 2014 and 1.73 per 100,000 population in 2015 and 2016. The most common cause of disability was amputation of frostbitten limbs (55.6\%), including $66.7 \%$ amputation of hands and $33.3 \%$ of legs. According to experts, official statistics reflect, at best, only about half of people with disabilities in society, which is due to a number of circumstances. First, some of the persons recognized as disabled by the results of the examination in the expert commissions do not apply to the social protection authorities. Second, since disability accounting is oriented toward the source of pension provision, people with disabilities who receive other kinds of pensions (by age, loss of breadwinner, etc.) do not fall into the general statistics.

Table 1.

The number of deaths in $R S(Y)$ as a result of road traffic accidents and CT in 2011-2015

\begin{tabular}{|l|c|c|c|c|c|c|c|c|c|c|c|c|}
\hline \multirow{2}{*}{$\begin{array}{l}\text { Causes of } \\
\text { mortality }\end{array}$} & \multicolumn{2}{|c|}{2011} & \multicolumn{2}{|c|}{2012} & \multicolumn{2}{|c|}{2013} & \multicolumn{2}{|c|}{2014} & \multicolumn{2}{|c|}{2015} & \multicolumn{2}{c|}{ Total } \\
\cline { 2 - 13 } & $\mathrm{n}$ & $\begin{array}{c}\text { per } \\
100,000 \\
\text { population }\end{array}$ & $\mathrm{n}$ & $\begin{array}{c}\text { per } \\
100,000 \\
\text { population }\end{array}$ & $\mathrm{n}$ & $\begin{array}{c}\text { per } \\
100,000 \\
\text { population }\end{array}$ & $\mathrm{n}$ & $\begin{array}{c}\text { per } \\
100,000 \\
\text { population }\end{array}$ & $\mathrm{n}$ & $\begin{array}{c}\text { per } \\
100,000 \\
\text { population }\end{array}$ & $\begin{array}{c}\text { per } \\
\mathrm{n} \\
100,000 \\
\text { population }\end{array}$ \\
\hline $\begin{array}{l}\text { Road } \\
\text { accidents }\end{array}$ & 157 & 16.4 & 134 & 14.0 & 156 & 16.3 & 140 & 14.6 & 75 & 7.8 & 662 & 13.8 \\
\hline $\mathrm{CT}$ & 195 & 20.4 & 164 & 17.6 & 150 & 15.7 & 158 & 16.5 & 145 & 15.1 & 812 & 17.0 \\
\hline
\end{tabular}


Table 2.

The number of patients who received treatment in the burn department of the Center for Emergency Medical Care of Yakutsk in 2014-2016

\begin{tabular}{|l|c|c|c|c|c|c|c|}
\hline \multirow{2}{*}{$\begin{array}{c}\text { Nosological } \\
\text { forms } \\
\text { (Code) }\end{array}$} & \multicolumn{2}{|c|}{2014} & \multicolumn{2}{c|}{2015} & \multicolumn{2}{c|}{2016} & \multirow{2}{*}{ Total } \\
\cline { 2 - 7 } & $\begin{array}{c}\text { discharged } \\
\text { after } \\
\text { treatment }\end{array}$ & deaths & $\begin{array}{c}\text { discharged } \\
\text { after } \\
\text { treatment }\end{array}$ & deaths & $\begin{array}{c}\text { discharged } \\
\text { after } \\
\text { treatment }\end{array}$ & deaths & 171 \\
\hline T33.2-T69.8 & 156 & 5 & 179 & 1 & 171 & 5 \\
\hline $\begin{array}{l}\text { including } \\
\text { children under } \\
\text { the age of 17 }\end{array}$ & 7 & - & 14 & - & 12 & - & 33 \\
\hline T34 & 57 & - & 64 & - & 58 & - & 179 \\
\hline $\begin{array}{l}\text { including } \\
\text { children under } \\
\text { the age of 17 }\end{array}$ & 1 & - & 2 & - & 2 & - & 5 \\
\hline T69.8 & 21 & - & 17 & - & 19 & - & 57 \\
\hline
\end{tabular}

Table 3.

Number of surgical interventions for frostbite in 2014-2016

\begin{tabular}{|l|c|c|c|c|}
\hline \multicolumn{1}{|c|}{ Type of surgery } & 2014 & 2015 & 2016 & Total \\
\hline Amputation of the extremities, including: & 52 & 67 & 68 & 187 \\
\hline - amputation at the level of the shins & 2 & 7 & 7 & 16 \\
\hline - hand amputation & - & - & 5 & 5 \\
\hline - amputation of the upper limb fingers & 28 & 30 & 24 & 82 \\
\hline - amputation of lower limb fingers & 19 & 24 & 13 & 56 \\
\hline - amputation at the level of the forearm & - & 1 & 3 & 4 \\
\hline - foot amputation & 3 & 5 & 16 & 24 \\
\hline Osteonecretomy & 5 & 19 & 3 & 27 \\
\hline Autodermoplasty & 12 & 13 & 3 & 28 \\
\hline Necroectomy & 4 & 5 & - & 9 \\
\hline Total & 73 & 104 & 74 & 251 \\
\hline
\end{tabular}

Third, disability accounting is departmental; therefore, some people with disabilities who receive pensions in other departments (the Ministry of Defense, the Ministry of Internal Affairs, the Federal Security Service) are also not included in the overall statistics.

Thus, on the example of RS(Y), the severity of the problem of EENC for the territories of the Far North is undeniable. The problem, as well as other external causes of mortality, is not only medical but also social, as it goes far beyond the competence of the health system. Two major adverse factors are to be noted: the lack of self-protective behavior and the spread of alcoholism, which play a leading role, as in the case of mortality from road traffic accidents. In other words, $\mathrm{CT}$ is a preventable factor of premature mortality and disability of people of mostly young age groups. The unfavorable background is the vast territory of $\mathrm{RS}(\mathrm{Y})$, the remoteness of settlements, lack of roads, and lack of infrastructure and a stable satellite connection for the timely call of help. This problem is especially acute in the arctic regions of the republic, and requires a special system of state measures to find a solution.

It is clear that the clinical course and outcome of CT depend on the timely diagnosis, scope and adequacy of first aid and the subsequent basic therapy and rehabilitation. At the same time, many questions concerning diagnostics and treatment tactics are not sufficiently disclosed or are contradictory. ${ }^{(5)}$ There are no unit recommendations or standards for treatment of victims with general cooling or frostbite. Many questions of management strategies to improve patients' treatment (preferable passive or active warming in hypothermia, extracorporeal methods, thrombolytic therapy), as well as timing for surgical treatment, are also unresolved. ${ }^{(3,6)}$ All the 
above-mentioned issues indicate the need to develop clinical guidelines for the diagnosis and treatment of $\mathrm{CT}$, based on the data of modern scientific research and accumulated practical experience.

\section{Competing interests} interests.

The authors declare that they have no competing

\section{References}

1. Meiman JG, Anderson H, Tomasallo CD. HypothermiaRelated Deaths - Wisconsin, 2014, and United States, 20032013. Available from: https://www.semanticscholar.org/paper/ Hypothermia-Related-Deaths- $\%$ E2\%80\%94-Wisconsin $\% 2 \mathrm{C}$ -
2014\%2C-and-Meiman-Anderson/9028c43b512bbecc $95 \mathrm{a} 440$ 950fcfaacf29aad55c

2. Brändström H, Johansson G, Giesbrecht GG, Ängquist KA, Haney MF. Accidental cold-related injury leading to hospitalization in northern Sweden: an eight-year retrospective analysis. Scand J Trauma Resusc Emerg Med. 2014; 22:6. doi: 10.1186/1757-7241-22-6.

3. Proceedings of the Interregional conference "Actual issues of thermal injury treatment." Yakutsk; 2015.

4. Ivanova A. Regional features of the premature mortality and economic damage assessment in the Republic of Sakha (Yakutia). Abstract of ScD Thesis. Moscow;2016. [In Russian]. 5. Jurkovich GJ. Environmental cold-induced injury. Surg Clin North Am. 2007;87(1):247-67, viii.

6. Aslam AF, Aslam AK, Vasavada BC. Khan IA. Hypothermia: evaluation, electrocardiographic manifestations, and management. Am J Med 2006;119(4):297-301. 